\title{
Supporting Cognitive Development through Multimedia Learning and Scientific Approach: An Experimental Study in Preschool
}

\author{
Evania Yafie $^{1,2, *}$, Besse Nirmala ${ }^{3}$, Lia Kurniawaty ${ }^{4}$, Tri Sugiarti M Bakri ${ }^{5}$, Anwar Bani Hani ${ }^{2}$, \\ Diana Setyaningsih ${ }^{6}$ \\ ${ }^{1}$ Faculty of Education, State University of Malang, Malang, 65145, East Java, Indonesia \\ ${ }^{2}$ Faculty of Social Science and Humanities, Universiti Teknologi Malaysia, Skudai, 81310, Johor, Malaysia \\ ${ }^{3}$ Faculty of Education, Tadulako University, Palu, 94111, Center of Sulawesi, Indonesia \\ ${ }^{4}$ Faculty of Education, Panca Sakti University, Bekasi, 17414, West Java, Indonesia \\ ${ }^{5}$ Faculty of Psychology, Makassar State University, Makassar, 90222, South Sulawesi, Indonesia \\ ${ }^{6}$ Faculty of Teacher Training and Education, Cenderawasih University, Jayapura, 99225, Papua, Indonesia
}

Received September 30, 2020; Revised November 1, 2020; Accepted November 7, 2020

\section{Cite This Paper in the following Citation Styles}

(a): [1] Evania Yafie, Besse Nirmala, Lia Kurniawati, Tri Sugiarti M Bakri, Anwar Bani Hani, Irfan Fauzi Rachmat , "Supporting Cognitive Development through Multimedia Learning and Scientific Approach: An Experimental Study in Preschool," Universal Journal of Educational Research, Vol. 8, No. 11C, pp. 113 - 123, 2020. DOI: 10.13189/ujer.2020.082313.

(b): Evania Yafie, Besse Nirmala, Lia Kurniawati, Tri Sugiarti M Bakri, Anwar Bani Hani, Irfan Fauzi Rachmat (2020). Supporting Cognitive Development through Multimedia Learning and Scientific Approach: An Experimental Study in Preschool. Universal Journal of Educational Research, 8(11C), 113 - 123. DOI: 10.13189/ujer.2020.082313.

Copyright $@ 2020$ by authors, all rights reserved. Authors agree that this article remains permanently open access under the terms of the Creative Commons Attribution License 4.0 International License

\begin{abstract}
Cognitive development is defined as a change in behavior that results in individuals obtaining, organizing, and implementing knowledge in reasoning and solving problems. This research aims to analyze the effect of multimedia learning and scientific approach on cognitive development. This research uses experimental quantitative research that divides research participants into an experimental group and a control group. The results show that there are differences in the mean scores of logical thinking, symbolic thinking, problem-solving in the pre-test and post-test where the post-test scores are higher, so it can be concluded that the two treatments in the control and experimental groups can improve children's cognitive development. Furthermore, the gain score value shows that the experimental group has a higher score meaning so that the experimental group is better than the control group. This is by the t-test which shows that the provision of multimedia learning with the scientific approach given to the experimental class is better than the control class which only uses the scientific approach.
\end{abstract}

Keywords Cognitive Development, Multimedia
Learning, Scientific Approach, Preschool

\section{Introduction}

Cognitive development is defined as a change in behavior that results in individuals obtaining, organizing, and implementing knowledge in reasoning and solving problems (Gauvain, 2016). Piaget considers that thinking is one of the differences between humans and animals that comes from social interactions (Huitt, \& Hummel, 2003). Early childhood cognitive development is at the motor-sensory stage ( $0-1.5$ years) and the pre-operational stage (1.5-6 years). In the motor-sensory step, knowledge is obtained through the interaction of senses and motor activity. In the pre-operational stage, children begin to understand the world with signs and symbols; egocentric thinking dominates with thoughts that cannot be changed (Huitt \& Hummel, 2003).

Cognitive development is one aspect that is sufficiently considered in early childhood education. Good cognitive 
development is in line with parents who think that children with high cognitive abilities are smart children (Aisyah et al., 2019). This results in a high intensity of learning that develops mental aspects in early childhood education. Cognitive development in the 2013 Curriculum is divided into three, namely: the ability to solve simple problems in everyday life with flexibility and be socially acceptable, implement knowledge or experience in new conditions, the ability to think logically; recognize differences, patterns, classification, initiative, planning, identify cause and effect and be able to think logically, Think logically: recognize differences, categories, patterns, take the initiative, plan, and recognize cause and effect, the ability to think symbolically; recognizes, mentions, and uses the symbol numbers $1-10$, recognizes the alphabet, and can represent various objects in the form of images (Yafie, et al., 2020)

The development of an increasingly modern era encourages cognitive abilities to be packaged in multimedia-based learning. The use of multimedia-based learning media can provide valuable benefits in developing aspects of child development in general and developing mental aspects in particular (Yafie et al., 2020). The use of multimedia in early childhood learning is following the current development of science and technology (science and technology). Multimedia-based education is carried out by presenting more varied words, images, and sounds. Images are modified to be more attractive by turning them into charts, illustrations, videos, or interactive illustrations (Mayer \& Moreno, 2003). The 21st-century era makes early childhood inseparable from the use of multimedia such as smartphones, televisions, and VCD players and gadgets (Yafie, et al., 2020). The use of multimedia-based learning is considered more effective and efficient in developing children's cognitive abilities because essentially learning by presenting images, sounds, and words in a more attractive manner will make it easier for children to think (Mayer, 2014).

Cognitive abilities are also defined as thinking skills (de Ribaupierre, 2015). The brain will more readily accept incoming information when it involves various senses (Mayer, 2014). Multimedia learning by combining sound, images, and audio into a more attractive form makes it easier for children to receive information, allowing for faster information processing. Yafie, et al. (2020) argue that the existence of multimedia-based learning also allows meaningful learning to occur because essentially, each individual will be involved in education by taking various relevant information received by the senses.

This is in line with the scientific approach principle, which wants learning to be able to do $5 \mathrm{M}$ scientific consisting of observing, asking questions, gathering information, reasoning, and communicating. Multimedia based learning media that combines audio, visual, and audio-visual can make it easier for teachers to apply the 5 M Scientifics, which are considered appropriate media.
Early childhood is in the stage of iconic thinking; (Children observe reality not directly, but through secondary sources, for example, through pictures or writing) and Symbolic; (Children make abstractions in the form of theories, interpretations, analyses of observed and natural reality, a person can have abstract ideas or ideas that are influenced by the ability to speak language and logic (Takaya, 2008)

Based on the above problems, learning media and approaches that are following the needs and developments of the times will be believed to increase the efficiency of early childhood learning. This research was conducted to analyze multimedia-based understanding and scientific approaches to children's cognitive development. Early childhood cognitive development, which is still in the iconic and symbolic stage, causes children not to think abstractly, so they need an appropriate medium and approach to developing cognitive abilities.

\section{Literature Review}

\subsection{Cognitive Development in Early Childhood}

Considering that Indonesia is a country with relatively high human resources, stimulation of cognitive development needs to be given. We must manage human resources adequately through consistent and sustainable forms of training and education (Yafie, 2019). Children have sensory sensitivity from birth to 3 years of age (Theo \& Martin, 2004). Cognitive potential in children themselves has increased by 50 percent since age 4 and 80 percent since age 8 (Brown, 1989). In the cognitive development theory introduced by Piaget (2002), it is claimed that the theory of cognitive development is a theory that describes how children respond to the world and perceive objects and events around them. The concept of further cognitive development is human thinking skills in which focus, memory, reasoning, imagination, and language are present (Papalia, 2007). As far as cognitive development is concerned, the desired result for children is that they can think objectively and critically, to have explanations, to be able to solve problems and to identify causal relationships in the solution of problems at hand (Yamin and Sanan, 2010: 150).

Early childhood still needs to see what they're all about. This great curiosity leads the children to search for facts and to infer what they have been looking for (Rahayu, Suryanti, Setiawan, 2019). The high desire for children does not mean that teachers and parents are insensitive to one another. On the contrary, proper stimulation of the cognitive aspect is indispensable in this era. Children can be stimulated by playing to suit their development (Rahayu, Suryanti, \& Setiawan, 2019). There are three fields of general knowledge in the cognitive field: first, the general knowledge area of science. Second, the idea of 
form, color, and scale. Third, the definition of numbers, symbols of numbers, and letters (Rahayu, Suryanti, Setiawan, 2019). To improve cognitive abilities in children, the teacher must provide children with enjoyable experiences in environments that are fun, healthy, and relaxed by using techniques, tools, resources, media this is easy to apply and motivates children to capture information well (Reny, 2013) where the end aim of all this is to allow children to have a greater chance of continuing to grow. By providing children with direct opportunities to carry out different learning activities, it can be a way of improving cognitive systems (Fardiah, Murwani, \&Dhieni, 2020). Human intelligence experience as part of a living organism will often evolve dynamically and undergo rapid changes as the organism is more biologically mature (Hergenhahn and Olso, 2008: 313). Cognitive processes encountered by an individual can be used to explain changes in the mind, intellect, and language of a person (Mulyani, 2017).

The characteristics of cognitive development of children aged 5 to 6 years include: being able to shape something using clay, calling and counting numbers 1 to 20 , recognizing the symbols of numbers, linking concepts and symbols of numbers, being able to understand the same concept as, larger, smaller, cause and effect, showing the oddity of a picture, knowing the cause of something that happens. Children need the advantages of cognitive ability to improve their awareness of what they see, hear, taste, touch, or smell through their senses. Cognitive development is also known as thinking capacity development or intellectual development in early childhood education institutions such as kindergartens, playgroups, and other similar educational institutions (Sujiono, 2013).

\subsection{Multimedia Learning}

The use of technology in the learning world is unavoidable. Based on the study submitted by eMarketer (2015), more people have opted to spend more time watching streaming videos than social media since 2015. Meanwhile, Cisco forecasts that the global market for video content on the Internet will rise by 80 percent in 2019. Industrial development is rapidly developing, such as entertainment content on Youtube, Netflix, and social media content for Facebook and education, such as school sites or online courses. Technology advances affect face-to-face learning. The first generation is still using the conventional face to face. The second generation is users of e-learning or distance learning, and the third generation enjoys blended learning (Dang, Zhang, Ravindran \& Osmonbekov, 2016). Multimedia learning offers a middle ground that becomes a solution for people who are limited by the ability to process knowledge. This, in turn, has given rise to several channel sources. One of the reasons the learning process must be revolutionized is that the current generation is experiencing development and many learning interactions are created in the form of online interactions (Cholifah et al., 2019). Dual-channel assumption means that humans process information separately for visually depicted content and auditors closely linked to dual-coding theory (Clark \& Paivio, 1991).

In the cognitive theory of multimedia learning proposed by Mayer (Mayer, 2005; Mayer \& Fiorella, 2014), it is claimed that if visual senses and auditory channels in working memory are used at the same stage, optimal learning will result. Research that increases the distribution of visual attention in multimedia learning also shows that creativity would be better in images if audio is also applied to written text (Wiebe \& Annetta, 2008). This shows that the way students learn is influenced by the audio help they get. The term multimedia learning by Mayer (1997) is also specifically established, which triggers the development of studies on the effects of separate attention that will later form the Cognitive Theory of Multimedia Learning (CTML) and the concepts surrounding it (Mayer \& Moreno, 1998). Mayer (1997) further describes that when words and images are visually displayed together, they can be used to describe the cognition that can form the foundation of a person's learning process.

In the late 1980 s to early 1990 s, early research on multimedia effects established a new theoretical paradigm that was useful for describing and predicting multimedia learning, such as the integration of text and image comprehension (Schnotz \& Bannert, 2003). Besides, the distribution of visual focus in evolving multimedia learning is typically dominated by written text rather than images (Schmidt-Weigand, Kohnert, and Glowalla, 2010). The new Cambridge Multimedia Learning Handbook addressed the role of collaboration, learning control, generative images, and advanced concepts of multimedia learning (Kischner, Kirschner, \& Janssen, 2014; Leutner \& Schmeck, 2014; Scheiter, 2014). Student learning outcomes may be connected to the processes they conduct, such as their ability to quickly grasp the movement of text and images when audio is introduced (Krejtz et al., 2012; Liu et al., 2011). Researchers researching this can produce results that reflect on the concepts of multimedia learning possessed by individuals who are not only limited to verbal knowledge (Adesope \& Nesbit, 2012) but also those linked to spatial skills (Höffler, 2010). Multimedia learning focuses on language skills through machine learning assistance (Abraham, 2008), through Virtual Reality learning (Santos et al., 2014), as well as interactive experiences encountered by learning participants (Gegenfurtner, Quesada-Pallarès, \& Knogler, 2014)). This will allow researchers and practitioners in the field of multimedia learning to promote collective needs, monitor students, provide input, and provide easier examples through effective multimedia training in a 
detailed, meaningful, and engaging manner.

Many representations can be created from existing learning materials into words and graphics to form a relationship between verbal and visual knowledge that encourages people to participate in active learning through the use of multimedia learning technology (Clark \& Mayer, 2016). There is an effect between the determinants of students' behavioral intentions when using multimedia-based learning with technology acceptance and the advantages of multimedia (Lee and Ryu, 2013). While multimedia learning is not widely used, the cognitive processes of multimedia learning attract the attention of several researchers (Desjarlais, 2017). Many findings, evaluations, and self-assessments about the processing of inferences are found in multimedia learning (Rodrigues \& Rosa, 2017). However, Mayer said that it required measurements that specifically display cognitive processes during multimedia learning (Mayer, 2017). While multimedia learning has many concepts that are derived from cognitive science assumptions, there is still a lack of empirical evidence to act as a guideline for cognitive processes. The onset of this deficiency stems from the difficulty in measuring cognitive processes, including multimedia components, cognitive load, and visual appearance (Liu \& Chuang, 2011).

\subsection{Scientific Approach}

The scientific approach is one of the learning processes that provide children with a complete learning experience, control, and strategy. This approach is so because the learning process's design is based on concepts, laws, and principles that carry through the stages of preparation formulating a hypothesis analyzing data with various techniques and producing ideas, rules, or regulations Foorman (1997). In the process, this approach also emphasizes learning activities carried out by students by peering, asking questions, reasoning, and trying to make conclusions (Feifer, 2008). This approach's characteristics aa by involving scientific process skills to construct ideas, laws, or principles of the cognitive processes presented here in the future. This approach can stimulate children's intellectual development, especially higher-order thinking skills that affect child character (Lawson, 1999).

The hope of applying this scientific approach itself is to understand that children have to understand various scientific materials that are useful for application in everyday life. This is because scientific learning can be applied at all levels of education to introduce the concept of daily life (Reilly, 2006). Through these conditions, it uses expected that children can understand so that they find out the source of observation information through and not only passively receiving information (Lawson, 1999). Scientific learning with an integrative thematic or thematic approach will provide a child with a complete and close learning experience. Children will understand something entirely and avoid partial understanding, which impacts children, which makes us solve daily problems in various creative ways (Yafie, 2019: 2).

Yafie (2019: 110) states that Scientific Approach Learning is essential to provide variety in teaching and learning activities using various methods. For example, experimentation, role-playing, responsibility, conversation. Science does not mean learning about science, but a way of knowing that is following established criteria and involves children directly in a pleasant atmosphere through providing full opportunities to try and discover for themselves the results of the learning process carried out (McCharty, 2005). Yafie (2019: 112) states that learning can be categorized as scientific as the criteria fulfill the following seven criteria:

1. The material given comes from a phenomenon or fact, not imaginary, and can be thought of from the logical cause

2. All explanations, responses, and discussions that are created are objective and not subjective and deviate from the flow of logical thinking

3. Learning that occurs can encourage and motivate children to be critical, analytical, and appropriate to identify, understand, solve problems, and apply what has been obtained

4. Encourage children to think ca when faced with differences, questions, and links to each other from the material they have

5. Able to encourage and inspire children to develop rational and objective thinking patterns when responding to learning materials

6. Based on concepts, theories, and empirical facts, which can be justified

7. Learning has clear and straightforward objectives but is still easy to implement.

\section{Method}

\subsection{Participant}

This research uses experimental quantitative research. The experimental design in this study is a nonrandomized pretest-posttest control group design, that divides research participants into an experimental group and a control group using two groups that already exist in the natural situation of the participants. The experimental group uses multimedia learning with a scientific approach and the control group uses only a scientific approach. This study involved 60 Kindergarten child with age between $4-5$ years and 30 children in each group.

\subsection{Procedure}

a). Preparation of learning plans with a scientific approach. The learning plan is designed to improve children's cognitive development. This learning plan 
contains topics, learning objectives, time allocation, learning activities using the scientific approach, and evaluation.

b). Development of multimedia learning. The developed learning multimedia focuses on the topic of plants and is developed by the developmental stages of children aged 4-5 years. This multimedia learning has several components such as material in the form of video, animation, pictures, sound, and evaluation in the form of games and quizzes (multiple-choice, sequences, matching, true and false, and word bank).

c). Preparation of research instruments. The research instrument is used to measure cognitive development which is modified from the cognitive assessment scale (Rao, et al., 2014) which consists of including IQ, language, logical thinking, symbolic thinking, executive functions, problem-solving, and academic achievement. In this study, researchers will only take three aspects, namely logical thinking, symbolic thinking, and problem-solving. The instrument is measured using 4 scales consisting of 4 (very good), 3 (good), 2 (sufficient), and 1 (less). d). Doing a pre-test. The pre-test was carried out to determine the cognitive level related to plant topics in the control group and the experimental group before being given treatment. The pre-test was carried out by conducting observations and closed interviews to find out the child's initial knowledge related to the topic and learning objectives, namely the parts of plants, shapes, colors, and tastes of fruits.

e). Implementation of learning. The learning implementation in the control group used the Scientific Approach while the Experiments group used multimedia learning with a scientific approach.

Table 1 shows that there are 6 (six) steps that must be applied in the scientific approach which include observing, collecting information/experimenting, asking, associating / processing information, communicating, and evaluating.

f). Post-test. Post-test was carried out by conducting observations and closed interviews to determine cognitive development with the topic and learning objectives, namely the parts of the plant, the shape, color, and taste of the fruits.

Table 1. Learning activity

\begin{tabular}{|c|c|c|}
\hline \multirow[b]{2}{*}{ Scientific approach activity } & \multicolumn{2}{|c|}{ Learning activity } \\
\hline & $\begin{array}{c}\text { Control group } \\
\text { (Scientific Approach) }\end{array}$ & $\begin{array}{c}\text { Experiments group } \\
\text { (Multimedia Learning with Scientific Approach) }\end{array}$ \\
\hline Observe & $\begin{array}{l}\text { Children observe the explanation of the } \\
\text { subject matter from the teacher with learning } \\
\text { resources from books }\end{array}$ & $\begin{array}{c}\text { Children observe the explanation of the subject matter } \\
\text { from the teacher with learning resources from } \\
\text { multimedia learning }\end{array}$ \\
\hline $\begin{array}{c}\text { Gather } \\
\text { information/experiment }\end{array}$ & $\begin{array}{l}\text { Children learn outside the classroom (in the } \\
\text { school garden) to gather information about } \\
\text { plants } \\
\text { Child experiments with the texture, color, } \\
\text { taste, and size of plant parts }\end{array}$ & $\begin{array}{c}\text { Children learn outside the classroom (in the school } \\
\text { garden) to gather information about plants guidance by } \\
\text { multimedia learning } \\
\text { Child experiments with the texture, color, taste, and size } \\
\text { of plant parts guidance by multimedia learning }\end{array}$ \\
\hline question and ask & $\begin{array}{l}\text { Teacher and child do questions and ask each } \\
\text { other regarding plant subject matter }\end{array}$ & $\begin{array}{l}\text { Teacher and child do questions and ask each other } \\
\text { regarding plant subject matter accompanied by examples } \\
\text { from multimedia }\end{array}$ \\
\hline $\begin{array}{l}\text { Associating / processing } \\
\text { information }\end{array}$ & $\begin{array}{l}\text { The child collecting groups the parts of the } \\
\text { plant according to the same texture, color, } \\
\text { taste, and size categories }\end{array}$ & $\begin{array}{c}\text { The child collecting groups the parts of the plant } \\
\text { according to the same texture, color, taste, and size } \\
\text { categories }\end{array}$ \\
\hline Communicating & $\begin{array}{l}\text { Children practice planting plant seeds in } \\
\text { discussions with their friends }\end{array}$ & $\begin{array}{l}\text { Children practice planting plant seeds in discussions with } \\
\text { their friends }\end{array}$ \\
\hline Evaluation & $\begin{array}{l}\text { Draw leaves and fruit shapes } \\
\text { Fill out the child's worksheet }\end{array}$ & $\begin{array}{c}\text { Draw leaves and fruit shapes } \\
\text { Play game, puzzle, and quiz in multimedia learning }\end{array}$ \\
\hline
\end{tabular}




\subsection{Data Analysis}

Data analysis uses an independent sample t-test which is a comparative test or different test to find out whether there is a significant difference mean between two independent groups on the interval or ratio data scale. The two independent groups referred to here are two groups that are not paired, meaning that the data sources come from two different subjects. The hypothesis of the independent sample t-test is accepted if the significant value is smaller than $0.05(p<0.05)$. This means that there is a difference in variable Y (cognitive development between the control group and the experimental group). Before the t-test is carried out, the variance similarity test (homogeneity) and the normality test is carried out. The normality test is carried out to see whether the data sample is the normal distribution or not. Normality testing is carried out by looking at Value on Kolmogorov-Smirnov. Data is normally distributed if the significance is greater than 0.05 . Similarity test of variance (homogeneity) with the $\mathrm{F}$ test (Levene's test). Data is said to be homogeneous if the significance is greater than 0.05 .

\section{Finding}

The main results of this study are to know the effectiveness of multimedia learning with a scientific approach to the differences in the cognitive development of children aged 4-5 years between the control group and the experimental group. However, before analyzing the hypothesis, the normality and homogeneity tests are first carried out.

\subsection{Normality Test}

The data normality test in the control and experimental group in this study used the Kolmogorov-Smirnov test statistic using the SPSS program. The results of the calculations are presented in Table 2.

Table 2. Normality Test

\begin{tabular}{|c|c|c|}
\hline Group & Asymp.sig (2-tailed) & Explanation \\
\hline Control & 0.738 & Normal \\
\hline Experiment & 0.467 & Normal \\
\hline
\end{tabular}

The results of the calculation show that the value of the Asym.Sig. (2-tailed) $>0.05$ so that the cognitive development data in the experimental group and control group are normally distributed. Thus, it can be concluded that the distribution of data in the two groups is normally distributed.

\subsection{Homogeneity Test}

A homogeneity test is used to find out whether the data have the same variance (homogeneous) or not.
Table 3. Homogeneity Test

\begin{tabular}{|c|c|c|c|}
\hline Variable & $\begin{array}{c}\text { Levene } \\
\text { Statistic }\end{array}$ & Sig. & Explanation \\
\hline $\begin{array}{c}\text { Cognitive } \\
\text { Development }\end{array}$ & 1.143 & 0.153 & Homogeny \\
\hline
\end{tabular}

Based on Table 3, it can be seen that the statistical significance values of the Levene test are 1.143 and this significant value is greater than the significance level of 0.05 (sig. $(0.153>0.05)$. So it can be concluded that the experimental group and the control group have the same variance.

\subsection{Hypothesis Testing}

To test the effectiveness of multimedia learning with a scientific approach to improving children's cognitive development, the independent sample t-test was used. The test results can be seen in Table 4 .

Table 4. Pre-test-post-test

\begin{tabular}{|c|c|c|c|c|c|c|c|}
\hline \multirow{2}{*}{ Group } & \multirow{2}{*}{ Variable } & \multicolumn{2}{|c|}{ Pre-Test } & \multicolumn{2}{|c|}{ Post-Test } & \multicolumn{2}{|c|}{ Gain } \\
\cline { 3 - 8 } & & $\mathrm{M}$ & $\mathrm{SD}$ & $\mathrm{M}$ & $\mathrm{SD}$ & $\mathrm{M}$ & $\mathrm{SD}$ \\
\hline \multirow{5}{*}{ Control } & $\begin{array}{c}\text { Logical } \\
\text { thinking }\end{array}$ & 2.17 & 0.41 & 3.11 & 0.49 & 0.94 & 0.11 \\
\cline { 2 - 8 } & $\begin{array}{c}\text { Symbolic } \\
\text { thinking }\end{array}$ & 2.24 & 0.38 & 3.09 & 0.42 & 0.85 & 0.14 \\
\cline { 2 - 8 } & $\begin{array}{c}\text { Problem } \\
\text { solving }\end{array}$ & 1.89 & 0.28 & 2.99 & 0.32 & 1.10 & 0.09 \\
\hline \multirow{5}{*}{ Experiment } & $\begin{array}{c}\text { Logical } \\
\text { thinking }\end{array}$ & 2.21 & 0.37 & 3.67 & 0.38 & 1.46 & 0.16 \\
\cline { 2 - 8 } & $\begin{array}{c}\text { Symbolic } \\
\text { thinking }\end{array}$ & 2.19 & 0.39 & 3.77 & 0.37 & 1.58 & 0.17 \\
\cline { 2 - 8 } & $\begin{array}{c}\text { Problem } \\
\text { solving }\end{array}$ & 1.88 & 0.30 & 3.34 & 0.32 & 1.46 & 0.08 \\
\hline
\end{tabular}

In table 4 it is known that there are differences in the mean scores of logical thinking, symbolic thinking, problem-solving in the pre-test and post-test where the post-test scores are higher, so it can be concluded that the two treatments in the control and experimental groups can improve children's cognitive development. Furthermore, the gain score value shows that the experimental group has a higher score meaning so that the experimental group is better than the control group.

Table 5. t-test

\begin{tabular}{|c|c|c|c|}
\hline $\begin{array}{c}\text { Cognitive development } \\
\text { Variable }\end{array}$ & t-statistic & Sig. & Explanation \\
\hline Logical thinking & 2.834 & 0.000 & Significant \\
\hline Symbolic thinking & 3.045 & 0.000 & Significant \\
\hline Problem solving & 2.352 & 0.000 & Significant \\
\hline
\end{tabular}

The results showed that sig. (2-tailed) is smaller than $\alpha=$ 0.05 (sig. 2-tailed $=0.000<0.05$ ), so $\mathrm{H} 0$ is rejected. Because $\mathrm{H} 0$ is rejected, it can be concluded that there are differences in cognitive development (logical thinking, symbolic thinking, problem-solving) of children aged 4-5 years between the control group and the experimental group. This shows that the provision of multimedia 
learning with the scientific approach given to the experimental class is better than the control class which only uses the scientific approach.

\section{Discussion}

Cognitive abilities are needed by children to develop their knowledge of what they see, hear, taste, touch or smell through their five senses which are useful to support other aspects of development such as motoric, social, emotional, and moral (Wieman, 2007). Aspects of cognitive development involve the ability to think creatively in solving problems and are automatic in speed in finding new solutions in routine processes. Thus education should help children hone skills in problem-solving, critical thinking, and creativity that is useful when the child is an adult (Ramdhani, Usodo, \& Subanti, 2017). Cognitive abilities, especially those related to logical thinking, symbolic thinking, and problem-solving, are very suitable to be developed with a scientific approach (Reid, 2008). Through the application of a scientific approach in the learning process, early childhood will acquire and understand scientific knowledge (Sari, et al., 2018).

The scientific approach in the learning process is designed so that students actively construct concepts, laws, or principles through the stages of observing (to identify or find problems), formulate problems, propose or formulate hypotheses, collect data with various techniques, analyze data, draw conclusions and communicating found concepts, laws or principles (Bensley \& Murtagh, 2012). The scientific approach provides understanding to students in recognizing, understanding various materials using a scientific approach, that information can come from anywhere, anytime, not depending on unidirectional information from the teacher (Camuffo, et al., 2020). The scientific approach is very effective in shaping the development of attitudes, skills, and knowledge of students. Through this scientific approach, students are invited to observe, ask, reason, formulate, conclude, and communicate so that students can correctly master the material being studied well. The introduction of the scientific process for early childhood is done by involving children directly in activities, namely doing, experiencing information search by asking, and finding out answers to understanding the world with amazing ideas. Scientific learning in early childhood is very important for many aspects of child development, especially cognitive development (Cangelosi \& Parisi, 2002).

In addition to a scientific approach, the use of multimedia learning can also improve children's cognitive understanding. Several research studies show that computers with multimedia components can improve children's cognitive (Vosniadou, et al., 2001). Several studies have shown that the use of technology has many potential benefits for children, and when used appropriately, they include 1) supporting cognitive and emotional development, and the development of children's social skills and cooperation; 2) helps in the emergence of letter recognition and mathematical thinking, 3) becomes a medium for play, 4) enhances and strengthens the relationship between children and adults, or provides adults with new ways to gain insight into children's thinking based on their needs, thus providing opportunities for better learning, 5) Facilitating the emergence of "new talent" or "multiple intelligence" in children (Hill \& Broadhurst, 2001).

The application of science will feel more real and meaningful if the application is close to the child's entire life. Children learn about real-world simulations through computer-based tasks; They are accustomed to utilizing cognitive mechanisms and gradually building knowledge with technological facilities in the form of situational and visual cues. From here, children can develop ideas, exercise, interact, collaborate, be creative, and finally learn (Grantham-McGregor et al., 2007). Preschoolers today enjoy much easier interaction with the support of many emerging technology companies. The latest research in 2012 concluded that tablets have increased with the highest users being early childhood aged 4-14 years ( $\mathrm{Li}$ et al., 2010). Researchers concluded that learning activities could improve reflective thinking skills and allow children to analyze and plan information scientifically if designed appropriately. The use of computers at home and school affect the improvement of an eye and hand coordination (Lee, et al., 2016). Problem management skills, spatial cognition, spatial representation, iconic skills, and visual attention skills when using children's computers, cell phones, and video games also improve computer use. The effectiveness of digital media compared to traditional media is more effective when used to hone cognitive skills. Children are also more able to develop memory skills when using computers than learning to use media without technology (Johnson \& Mayer, 2010).

Learning multimedia was chosen because it has unique advantages compared to other media. According to (Homer, Plass, \& Blake, 2008) these advantages include: (1) mixed media, integrating various existing conventional media into one type of interactive media. Cognitive and language learning in schools certainly requires more than one media, both visual and audio media, with multimedia these media can be packaged in one form; (2) user control, allowing users to browse teaching materials according to their abilities and background knowledge. Children can access the material they need and process information independently, so that information absorption will be more effective (Brunken, Plass, \& Leutner 2003). (3) Simulation and visualization, with animation, simulation, and visualization technology, users will get more real and abstract information. For children, new information is still in the form of something abstract, for that we need media 
that can be used to help absorb the information; (4) different learning styles, multimedia has the potential to accommodate users with different learning styles. Children have different learning styles. Children with a tendency to auditory learning styles can absorb information when using audio, visual media using images and videos, kinesthetic with movement. Multimedia can combine the media used so that differences in children's learning styles can be resolving (Mayer, 2014).

The use of interactive multimedia learning in the classroom is supported by the results of research conducted by Mayer (2014) which states that multimedia has obtained many benefits from its use. Learning gain is $56 \%$ greater, learning consistency is better $50-60 \%$ and content retention is $25-50 \%$ higher (Alemdag \& Cagiltay, 2018).). Based on the results of these studies, learning multimedia can be said to be a medium that has enormous potential in helping the learning process. Children aged 4-5 years (group A) have developmental achievement targets that must be achieved in learning in kindergarten. To achieve this target requires stimulation of these aspects through learning activities with the concept of learning while playing. In this study, the developed multimedia is aimed at stimulating children with cognitive and language aspects following the applied curriculum and problems that occur in kindergarten. The developed multimedia is expected to be able to provide unique stimulation in the form of attraction and motivation in learning (Anmarkrud, Andresen, \& Bråten, 2019).

\section{Conclusion}

The results showed that there are differences in the mean scores of logical thinking, symbolic thinking, problem-solving in the pre-test and post-test where the post-test scores are higher, so it can be concluded that the two treatments in the control and experimental groups can improve children's cognitive development. Furthermore, the gain score value shows that the experimental group has a higher score meaning so that the experimental group is better than the control group. This is by the t-test which shows that the provision of multimedia learning with the scientific approach given to the experimental class is better than the control class which only uses the scientific approach.

\section{Acknowledgments}

We are very grateful to experts for their appropriate and constructive suggestions to improve this article.

\section{REFERENCES}

[1] Alemdag, E., \& Cagiltay, K. (2018). A systematic review of eye tracking research on multimedia learning. Computers \&
Education, 125, 413-428.

[2] Aisyah, E. N., Iriyanto, T., Astuti, W., \& Yafie, E. (2019). Pengembangan Alat Permainan Ritatoon Tentang Binatang Peliharaan sebagai Media Stimulasi Kemampuan Kognitif Anak Usia Dini. Journal Kajian Teknologi Pendidikan, 2(3), 174-180.

[3] Anmarkrud, Ø., Andresen, A., \& Bråten, I. (2019). Cognitive load and working memory in multimedia learning: Conceptual and measurement issues. Educational Psychologist, 54(2), 61-83.

[4] Bensley, D. A., \& Murtagh, M. P. (2012). Guidelines for a scientific approach to critical thinking assessment. Teaching of Psychology, 39(1), 5-16.

[5] Brunken, R., Plass, J. L., \& Leutner, D. (2003). Direct measurement of cognitive load in multimedia learning. Educational psychologist, 38(1), 53-61.

[6] Camuffo, A., Cordova, A., Gambardella, A., \& Spina, C. (2020). A scientific approach to entrepreneurial decision making: Evidence from a randomized control trial. Management Science, 66(2), 564-586.

[7] Cangelosi, A., \& Parisi, D. (2002). Computer simulation: A new scientific approach to the study of language evolution. In Simulating the evolution of language (pp. 3-28). Springer, London.

[8] de Ribaupierre, A. (2015). Piaget's Theory of Cognitive Development. In International Encyclopedia of the Social \& Behavioral Sciences: Second Edition.

[9] Grantham-McGregor, S, Cheung, YB, Cueto, S, Glewwe, P, Richter, L, Strupp, B (2007) Developmental potential in the first 5 years for children in developing countries. The Lancet 369: 60-70.

[10] Homer, B. D., Plass, J. L., \& Blake, L. (2008). The effects of video on cognitive load and social presence in multimedia-learning. Computers in Human Behavior, 24(3), 786-797.

[11] Johnson, C. I., \& Mayer, R. E. (2010). Applying the self-explanation principle to multimedia learning in a computer-based game-like environment. Computers in Human Behavior, 26(6), 1246-1252.

[12] Lee, H., Parsons, D., Kwon, G., Kim, J., Petrova, K., Jeong, E., \& Ryu, H. (2016). Cooperation begins: Encouraging critical thinking skills through cooperative reciprocity using a mobile learning game. Computers \& Education, 97, 97-115.

[13] Leutner, D. (2014). Motivation and emotion as mediators in multimedia learning. Learning and Instruction, 29, 174-175.

[14] Li, S. C., Pow, J. W., Wong, E. M., \& Fung, A. C. (2010). Empowering student learning through Tablet PCs: A case study. Education and Information Technologies, 15(3), 171-180.

[15] Mayer, R. E. (2014). Incorporating motivation into multimedia learning. Learning and Instruction, 29, 171-173.

[16] Ramdhani, M. R., Usodo, B., \& Subanti, S. (2017, September). Discovery learning with scientific approach on geometry. In Journal of Physics: Conference Series (Vol. 895, No. 1, p. 012033). IOP Publishing. 
[17] Rao, N., Sun, J., Wong, J. M. S., Weekes, B., Ip, P., Shaeffer, S., \& Lee, D. (2014). Early childhood development and cognitive development in developing countries: A rigorous literature review. Department for International Development.

[18] Reid, N. (2008). A scientific approach to the teaching of chemistry. What do we know about how students learn in the sciences, and how can we make our teaching match this to maximise performance?. Chemistry Education Research and Practice, 9(1), 51-59.

[19] Sari, S., Aryana, D. M., Subarkah, C. Z., \& Ramdhani, M. A. (2018, January). Multimedia based on scientific approach for periodic system of element. In IOP Conference Series: Materials Science and Engineering (Vol. 288, No. 1, p. 012137).

[20] Vosniadou, S., Ioannides, C., Dimitrakopoulou, A., \& Papademetriou, E. (2001). Designing learning environments to promote conceptual change in science. Learning and instruction, 11(4-5), 381-419.

[21] Wieman, C. (2007). Why not try a scientific approach to science education?. Change: The Magazine of Higher Learning, 39(5), 9-15.

[22] Abraham, L. B. (2008). Computer-mediated glosses in second language reading comprehension and vocabulary learning: A meta-analysis. Computer Assisted Language Learning, 21(3), 199-226.

[23] Adesope, O. O., \& Nesbit, J. C. (2012). Verbal redundancy in multimedia learning environments: A meta-analysis. Journal of Educational Psychology, 104(1), 250-263.

[24] Brown JE. (1989). Nutrition through the life cycle. United State of America: Wardsworth.

[25] Clark, J., \& Paivio, A. (1991). Dual coding theory and education. Educational Psychology REview, 3, 149-210.

[26] Clark, R., \& Mayer, R. (2016). E-Learning and the Science of Instruction: Proven Guidelines for Consumers and Designers of Multimedia Learning: John Wiley \& Sons

[27] Dang, Y. M., Zhang, Y. G., Ravindran, S., \& Osmonbekov, T. (2016). Examining Student Satisfaction and Gender Differences in Technology-Supported, Blended Learning. Journal of Information Systems Education, 27(2).

[28] Foorman, B., Fletcher, J., \& Francis, D. (1997). A scientific approach to reading instruction. Learning Disabilities Online.

[29] Desjarlais, M. (2017). The use of eye gaze to understand multimedia learning. In C. Was, F. Sansost, \& B. Morris (Eds.), Eye-tracking technology applications in educational research (pp. 122-142). Hershey PA, USA: Information Science Reference.

[30] eMarketer (Producer). (2015). Average Time Spent per Day on Select Digital Activities by US Adult Users of Each Medium. Retrieved from

[31] Fardiah, Murwani, S., Dhieni., N. (2020). Meningkatkan Kemampuan Kognitif Anak Usia Dini melalui Pembelajaran Sains. Jurnal Obsesi: Pendidikan Anak Usia Dini. 4 (1). 133-140.

[32] Gauvain, M., \& R, R. (2016). Cognitive Development. In
Encyclopedia of Mental Health (Second Edition) (pp. 317323).

[33] Gegenfurtner, A., Quesada-Pallarès, C., \& Knogler, M. (2014). Digital simulation-based training: A meta-analysis. British Journal of Educational Technology, 45(6), 1097 1114.

[34] Ginns, P. (2005). Meta-analysis of the modality effect. Learning and Instruction, 15(4), 313-331

[35] Hartanto, A. (2013). Pembelajaran Matematika Materi Bangun Ruang Balok Dengan Aplikasi Multimedia Interaktif di SD Negeri Teguhan Sragen. Seminar Riset Unggulan Nasional Informatika Dan Komputer FTI UNSA, 2(1).

[36] Hergenhahn, B.R dan Olson, Matthew H.(2010). Theories of Learning. Jakarta: Kencana PRenada Media Group. Jakarta

[37] Höffler, T. N. (2010). Spatial ability: Its influence on learning with visualizations - a meta-analytic review. Educational Psychology Review, 22(3), 245-269.

[38] Lawson, A. E. (1999). A scientific approach to teaching about evolution \& special creation. The American Biology Teacher, 61(4), 266-274.

[39] Gauvain, M., \& R, R. (2016). Cognitive Development. In Encyclopedia of Mental Health (Second Edition) (pp. 317323).

[40] Hartanto, A. (2013). Pembelajaran Matematika Materi Bangun Ruang Balok Dengan Aplikasi Multimedia Interaktif Di Sd Negeri Teguhan Sragen. Seminar Riset Unggulan Nasional Informatika Dan Komputer FTI UNSA, 2(1).

[41] Huitt, W., \& Hummel, J. (2003). Piaget’s theory of cognitive development. Educational Psychology Interactive, 3(2), 1-5.

[42] Kirschner, P. A., Kirschner, F., \& Janssen, J. (2014). The collaboration principle in multimedia learning. In R. E.

[43] Krejtz, I., Szarkowska, A., Krejtz, K., Walczak, A., \& Duchowski, A. (2012, March). Audio description as an aural guide of children's visual attention: Evidence from an eye-tracking study. In Proceedings of the symposium on eye tracking research and applications (pp. 99-106). ACM.

[44] Lee, D. Y., \& Shin, D. (2011). Effects of spatial ability and richness of motion cue on learning in mechanically complex domain. Computers in Human Behavior, 27(5), 1665-1674. doi:https://doi.org/10.1016/j.chb.2011.02.005

[45] Leutner, D., \& Schmeck, A. (2014). The generative drawing principle in multimedia learning. In R. E. Mayer (Ed.). Cambridge handbooks in psychology. The Cambridge handbook of multimedia learning (pp. 433-448). New York, NY, US: Cambridge University Press.

[46] Liu, H. C., Lai, M. L., \& Chuang, H. H. (2011). Using eye-tracking technology to investigate the redundant effect of multimedia web pages on viewers' cognitive processes. Computers in Human Behavior, 27(6), 2410-2417.

[47] Liu, H. C., \& Chuang, H. H. (2011). An examination of cognitive processing of multimedia information based on viewers' eye movements. Interactive Learning Environments, 19(5), 503-517.

[48] Mayer, R. E. (1997). Multimedia learning: Are we asking the 
right questions? Educational Psychologist, 32(1), 1-19

[49] Mayer, R. E., \& Moreno, R. (1998). A split-attention effect in multimedia learning: Evidence for dual processing systems in working memory. Journal of Educational Psychology, 90(2), 312-320.

[50] Mayer, R. E., \& Moreno, R. (2003). Nine ways to reduce cognitive load in multimedia learning. Educational Psychologist.

[51] Mayer, R. E. (2005). Cognitive theory of multimedia learning (Vol. 43). The Cambridge Handbook of Multimedia Learning.

[52] Mayer, R. E., \& Fiorella, L. (2014). 12 principles for reducing extraneous processing in multimedia learning: Coherence, signaling, redundancy, spatial contiguity, and temporal contiguity principles. In The Cambridge handbook of multimedia learning (Vol. 279).

[53] Mayer, R. E. (2017). Using multimedia for e Journal of Computer Assisted Learning, 1-21.

[54] Mulyani, N. (2017). Upaya Meningkatkan Perkembangan Sosial Emosional Anak Usia Dini. Jurnal Ilmiah Mahasiswa Raushan Fikr.

[55] Nugroho, P. (2015). Pandangan Kognitifisme Dan Aplikasinya Dalam Pembelajaran Pendidikan Agama Islam Anak Usia Dini. 3(2).

[56] Padilla, M. J. (1990). The science process skills. Research Matters-to the science Teacher, 9004

[57] Papalia, D., Olds S., Feldman R. (2007). Human development. 9th ed. New York: Mc. Graw Hill.

[58] Piaget, Jean. (2002). Tingkat Perkembangan Kognitif. Jakarta: Gramedia.

[59] Rahayu, D., R. (2013). Pengaruh Penggunaan Video Kartun Mencampur Warna Terhadap Kemampuan Kognitif Pada Anak Kelompok B di TK Terpadu Alhidayah II Ds. Bakung Kec. Udanawu Kab. Blitar. PAUD Teratai, 2(2).

[60] Reilly, T. (2006). The science of training-soccer: A scientific approach to developing strength, speed and endurance. Routledge.

[61] Richter, J., Scheiter, K., \& Eitel, A. (2016). Signaling text-picture relations in multimedia learning: A comprehensive meta-analysis. Educational Research Review, 17, 19-36

[62] Rodrigues, P., \& Rosa, P. (2017). Eye-tracking as a research methodology in educational context. In C. Was, F. Sansost, \& B. Morris (Eds.), Eye tracking technology applications in educational research (pp. 1-26). Hershey PA, USA: Information Science Reference.

[63] Feifer, S. G. (2008). Integrating response to intervention (RTI) with neuropsychology: A scientific approach to reading. Psychology in the Schools, 45(9), 812-825.

[64] Santos, M. E. C., Chen, A., Taketomi, T., Yamamoto, G., Miyazaki, J., \& Kato, H. (2014). Augmented reality learning experiences: Survey of prototype design and evaluation. IEEE Transactions on Learning Technologies, 7(1), 38-56

[65] Scheiter, K., \& Gerjets, P. (2007). Learner control in hypermedia environments. Educational Psychology Review, 19(3), 285-307

[66] Scheiter, K. (2014). The learner control principle in multimedia learning. In R. E. Mayer (Ed.). Cambridge handbooks in psychology. The Cambridge handbook of multimedia learning (pp. 487-512). New York, NY, US: Cambridge University Press.

[67] Schneider, S., Beege, M., Nebel, S., \& Rey, G. D. (2018). A meta-analysis of how signaling affects learning with media. Educational Research Review, 23, 1-24.

[68] Schmidt-Weigand, F., Kohnert, A., \& Glowalla, U. (2010). A closer look at split visual attention in system-and self-paced instruction in multimedia learning. Learning and Instruction, 20(2), 100-110.

[69] Schnotz, W., \& Bannert, M. (2003). Construction and interference in learning from multiple representation. Learning and Instruction, 13(2), 141-156. -learning

[70] Shih, Yi-Huang. (2020). Life Education for Young Children in Taiwanese Preschools: Meaning, Aspects and Teaching Methods. Universal Journal of Educational Research. Vol 8(4). 1246-1251

[71] Sujiono, Y. N. (2013). Hakikat Pengembangan Kognitif. Metode Pengembangan Kognitif.

[72] Suyanto, S. (2012). Pendidikan Karakter untuk Anak Usia Dini. Pendidikan Karakter Untuk Anak Usia Dini.

[73] Takaya, K. (2008). Jerome Bruner's theory of education: From early Bruner to later Bruner. Interchange. https://doi.org/10.1007/s10780-008-9039-2

[74] Tatminingsih, S. (2019). Alternatif Stimulasi Kemampuan Kognitif melalui Penerapan Model Pembelajaran Berbasis Permainan Komprehensif. Jurnal Obsesi : Jurnal Pendidikan Anak Usia Dini, 3(1), 183-190. https://doi.org/https://doi.or g/10.31004/obsesi.v3i1.130

[75] Theo, R \& Martin, H. Pendidikan Anak usia dini: tuntunan psikologis dan pedagogis bagi pendidik dan orang tua. 2004. Jakarta: PT Gramedia Widiasarana.

[76] Ulfa, S. (2016). Pemanfaatan Teknologi Bergerak sebagai Media Pembelajaran bagi Anak Usia Dini. 1(1).

[77] Ulfah, St. M., Arismunandar, Ahmad, M. A. (2020). Development of Traditional Creative Game Models to Improve Cognitive Ability in Early Childhood: A Preliminary Study. Universal Journal of Educational Research Vol 8(11). 5106-5113

[78] Ulfatun, N. (2020). Pemanfaatan Teknologi dalam Pendidikan Anak Usia Dini. 8(1).

[79] Wiebe, E., \& Annetta, L. (2008). Influences on visual attentional distribution in multimedia instruction. Journal of Educational Multimedia and Hypermedia, 17(2), 259-277.

[80] Yafie, E. (2019). Pengembangan Kognitif (Sains pada Anak Usia Dini). Malang: Universitas Negeri Malang.

[81] McCarthy, C. B. (2005). Effects of thematic-based, hands-on science teaching versus a textbook approach for students with disabilities. Journal of Research in Science Teaching: The Official Journal of the National Association for Research in Science Teaching, 42(3), 245-263. 
[82] Cholifah, P. S., Oktaviani, H. I., Nuraini, N. L. S., Meidina, A. M., Wanodyaningtiyas, R. F., \& Yafie, E. (2019, October). Online Project-Based Learning for Improving the Innovative Initiation during Diffusion and Innovation Course. In 2019 5th International Conference on Education and Technology (ICET) (pp. 55-60). IEEE.

[83] Yafie, E., \& Haqqi, Y. A. (2019). Development Application "Detection of Growth and Development for New Born Until Two Years" Based on Android. International Journal of Recent Technology and Engineering (IJRTE) ISSN: 2277-3878, Volume-8 Issue-2S9

[84] Yafie, E., Haqqi, A. Y., Kustiawan, U., Astuti, W., \& Ilhami,
S. B. (2020). The Effect of Teacher Competency Training on High Order Thinking-Based Learning. JECCE (Journal of Early Childhood Care and Education), 2(2), 87-93.

[85] Yafie, E., Samah, N. A., Mohamed, H., \& Haqqi, A. Y. (2020). Collaborative Mobile Seamless Learning (CMSL) based on Android Apps to Improving Critical Thinking in Higher Education in the Post-Covid-19 Era. Jour of Adv Research in Dynamical \& Control Systems, 12(07), 428441.

[86] Yamin, H. Martinis dan Sanan, Sabri Jamilah. (2010).Panduan Pendidikan Anak Usia Dini. Jakarta: GP Press. 